\title{
Targeting secreted heat shock protein-90alpha (Hsp90 $\alpha$ ) to prevent breast cancer progression
}

\author{
Zhengwei Zhao, Chieh-Fang Cheng, Rosie Kim, Mei Chen, David T Woodley, Wei Li \\ From 16th International Charles Heidelberger Symposium on Cancer Research \\ Coimbra, Portugal. 26-28 September 2010
}

Heat shock protein 90 (Hsp90) has been historically known as an abundant and intracellular ATP-driven chaperone with more than 100 target proteins that often play critical roles in various branches of the signaling networks for control of cell metabolism, survival, growth and differentiation. In many cancers, Hsp90 is either over-expressed or over-activated and it, therefore, becomes a target for anti-cancer drugs with a hope to simultaneously shut down multiple constitutively activated oncogene products in cancer cells. Despite of the high expectations, the toxicity of geldanamycin (GM)derived inhibitors in humans has been a long-standing hurdle. However, studies of past few years have demonstrated a surprising need for cancer cells to secrete Hsp90 $\alpha$ for tissue invasion and metastasis. I will present here new evidence that the metastatic breast cancer cells, MDA-MB-231, constitutively secrete Hsp90 $\alpha$ due to their constitutive expression of the hypoxia-inducible factor-1alpha (HIF1 $\alpha$ ). Down-regulation of either HIF1 $\alpha$ or HIF $1 \beta$ completely blocked Hsp $90 \alpha$ secretion. The main function of the secreted Hsp90 $\alpha$ is to promote breast cancer cell motility via binding to the cell surface lipoprotein receptor LRP1 (LDL Receptor-Related Protein-1). We have mapped this important extracellular Hsp90 $\alpha$ function to a 27 -amino acid peptide located at the boundary between the linker region (LR) and the middle domain (M) of Hsp90a. Selective inhibition of the extracellular action of Hsp90 or down-regulation of LRP-1 receptor blocked breast cancer invasion in an in vitro matrigel assay and tumor formation in nude mice. Most intriguingly, since secretion of Hsp90 $\alpha$ was only found to occur under pathological conditions such

\footnotetext{
* Correspondence: wli@usc.edu

Department of Dermatology and the USC-Norris Comprehensive Cancer Center, The University of Southern California Keck School of Medicine, Los Angeles, CA, USA

Full list of author information is available at the end of the article
}

as cancer and is not part of normal cells' life, anticancer drugs targeting the 27-amino acid peptide of the extracellular Hsp90 $\alpha$ should be more effective and less toxic in humans. We propose that the novel "secreted Hsp90-LRP1 Receptor" autocrine signaling plays a role in breast cancer progression and the extracellular, not intracellular, Hsp90 $\alpha$ is an effective and safer target for anti-cancer therapies.

Published: 24 September 2010

\section{doi:}

Cite this article as: Zhao et al:: Targeting secreted heat shock protein90alpha $(\mathrm{Hsp} 90 \alpha)$ to prevent breast cancer progression. BMC Proceedings 2010 4(Suppl 2):014.

\author{
Submit your next manuscript to BioMed Central \\ and take full advantage of: \\ - Convenient online submission \\ - Thorough peer review \\ - No space constraints or color figure charges \\ - Immediate publication on acceptance \\ - Inclusion in PubMed, CAS, Scopus and Google Scholar \\ - Research which is freely available for redistribution \\ Submit your manuscript at \\ www.biomedcentral.com/submit
}

